\title{
ANALISIS KESALAHAN PADA TEKS EKSPOSITORI BAHASA INGGRIS HASIL UJIAN MATA KULIAH ENGLISH 1 MAHASISWA JURUSAN ADMINISTRASI NIAGA POLITEKNIK NEGERI JAKARTA
}

\author{
Anwar Mustofa' ${ }^{1)}$, Supriatnoko') \\ ${ }^{1}$ Jurusan Administrasi Niaga, Politeknik Negeri Jakarta \\ ${ }^{2}$ Jurusan Akuntansi, Politeknik Negeri Jakarta \\ E-mail: ${ }^{1}$ anwarmustofa64@yahoo.com, ${ }^{2}$ supriatnoko@yahoo.co.id
}

\begin{abstract}
The research aims at analyzing semester 1 students' average abilities of Business Administration Department State Polytechnic of Jakarta in writing expository text in English 1 subject through error analysis approach. The data is then measured by the following standard English grammar books-Harbrace College Handbook (1977), Common Mistakes in English (1982), dan A Practical English Grammar (1982). By qualitative analysis, the research found out that: (1) students made mistakes in verb agreement with the subject and forgot verb/be to fill the predicate slot, (2) students opened a sentence with number or/and sometimes with conjunction, (3) students also forgot to use capital letter to begin a new sentence, as a name of an object, and also made mistakes in noun pluralization, (4) students also still did not know how to make derivational words and how to make noun phrase, and (5) students also did not aware of the function and meaning of the mechanic of writing such as full stop, comma, and semicolon in a sentence construction. Beside that, students came from vocational secondary schools had better writing skill than students from secondary schools; and hence female students proved to have better abilities in English writing skill than the male counterparts.
\end{abstract}

Keywords: error analysis, expository text, final test, writing skill

\begin{abstract}
Abstrak
Penelitian ini bertujuan menganalisis kemampuan mahasiswa dan mengukur tingkat kemampuan rata-rata mahasiswa semester 1 dalam berbahasa Inggris tulis pada Mata Kuliah English 1 melalui analisis kesalahan (error analysis) terhadap hasil Ujian Akhir Semester 1 yang berupa teks ekspositori. Penelitian ini mengambil tempat di Jurusan Administrasi Niaga, menggunakan pendekatan kualitatif. Data dikumpulkan dengan menggunakan teknik tes menulis. Data yang telah terkumpul diukur kebenarannya dengan menggunakan standar baku pada buku Harbrace College Handbook (1977), Common Mistakes in English (1982), dan A Practical English Grammar (1982). Penelitian ini memperoleh beberapa temuan sebagai berikut: yaitu (1) mahasiswa lupa memasang kata kerja atau to be yang berfungsi sebagai predikat, untuk kesesuaian subjek dan predikat, (2) mahasiswa menggunakan kata hubung dan angka untuk mengawali sebuah kalimat. (3) mahasiswa lupa menggunakan huruf kapital untuk mengawali kalimat atau untuk nama sebuah objek dan bentuk jamak sebuah kata benda (pluralization), (4) mahasiswa belum memahami tentang bentuk kata (derivation) dan kata majemuk (noun phrase), dan (5) mahasiswa belum memahami fungsi tanda baca khususnya "titik", “koma”, dan "titik koma” pada kalimat. Mahasiswa yang berasal dari SMK ternyata memiliki kemampuan yang lebih baik dibanding mahasiswa yang berasal dari SMU untuk membuat teks ekspositori meskipun jumlah mereka lebih sedikit
\end{abstract}


dibanding mahasiswa yang berasal dari SMU. Peserta didik wanita mendapatkan hasil yang lebih baik dibanding peserta didik pria dalam membuat teks ekspositori.

Kata kunci: analisis kesalahan, teks ekspositori, ujian akhir semester, keterampilan menulis.

\section{PENDAHULUAN}

Analisis kesalahan Bahasa (error analysis) adalah salah satu alat yang dapat digunakan untuk mengidentifikasi kesalahan-kesalahan di dalam menguasai suatu bahasa. Supriatnoko dan Nurhasyim (1993), Supriatnoko dan Ade Sukma Mulya (2005) menggunakan analisis kesalahan (error analysis) untuk mengkaji kesalahan penggunaan bahasa Indonesia dan kesalahan bahasa Inggris dalam artikel jurnal ilmiah. Muh. Arief Muhsin (2016) juga menggunakan analisis kesalahan (error analysis) untuk mengkaji kesalahan dalam membuat kalimat berbahasa Inggris yang dibuat pelajar kelas 8 di Makasar. Salah satu dari hasil penelitiannya adalah guru/dosen diharapkan menekankan pada keterampilan menulis.

Fisher \& Frey, dalam Sejnost, R.L. \& Thiese, S.M. (2010) menjelaskan bahwa teks ekspository sangat berbeda sekali dari teks naratif dalam hal nada, gaya, struktur, dan ciri-cirinya. Pertama, dalam teks ekspositori terkandung otoritas karena penulis memiliki data yang otentik dan akurat tentang topik yang ditulisnya. Kedua, gaya penulisan teks epository adalah jelas dan tidak berbelit-belit karena penulisannya berawal dari fakta yang umum ke fakta yang spesifik dan dari abstrak ke konkrit. Menurut Burke, dalam Sejnost, R.L. \& Thiese, S.M. (2010), teks ekspository menggunakan struktur kalimat dan gaya penulisan yang spesifik untuk menjelaskan informasi. Struktur kalimat yang dimaksud adalah present tense dan atau past tense sedangkan gaya penulisannya biasanya adalah sebabakibat (cause-effect), perbandingan (comparison and contrast), definisi-contoh (definition-examples), masalah-solusi (problem-solution), dan pengurutan data (proposition supporter sequential listing).

Keterampilan menulis merupakan salah satu jenis keterampilan berbahasa yang harus dikuasai seorang mahasiswa yang ingin menguasai bahasa asing. Seorang yang pandai menulis dapat diasumsikan sebagai terampil dalam bahasa yang ditulisnya tersebut. Menurut Abbas (2006), keterampilan menulis adalah kemampuan mengungkapkan gagasan, pendapat, dan perasaan kepada pihak lain melalui bahasa tulis.

Ketepatan pengungkapan gagasan harus didukung dengan ketepatan bahasa yang digunakan, kosakata dan gramatikal dan penggunaan ejaan. Untuk menghindari contek menyontek selama ujian berlangsung, midtest dan final test Mata kuliah English 1 di jurusan Administrasi Niaga dilakukan secara tertulis dalam bentuk pemaparan (teks ekspositori) dalam waktu 80 menit. Sebelumnya, mahasiswa diberi tahu tentang materi ujian dan diminta untuk menyiapkannya di rumah sehiigga ketika mereka berada di ruang ujian, mahasiswa tinggal menulis ulang apa yang telah disiapkannya di rumah.

Pada ujian tengah semester (mid semester test) mahasiswa diminta untuk mempromosikan sekolah menengah sebelumnya baik yang kejuruan maupun umum sedangkan pada ujian akhir semester (final test) mahasiswa diminta mempromosikan kota Jakarta. Ujian tengah semester merupakan rangkuman dari topik ke-1 sampai ke-4 sedangkan ujian akhir semester merupakan rangkuman dari topik ke-5 sampai ke-11. Penelitian ini hanya difokuskan pada 
Ujian Akhir Semester English 1. Kesalahan yang diteliti mencakup analisis kesalahan pada tataran bahasa/linguistik, pada tataran bentuk, dan penggunaan tanda baca.

\section{METODE PENELITIAN}

Penelitian ini mengambil tempat di Jurusan Administrasi Niaga Politeknik Negeri Jakarta dan dilaksanakan selama 6 bulan (Mei s.d. November 2018). Populasi penelitian ini adalah seluruh mahasiswa semester 1 Jurusan Administrasi Niaga Program Studi D3 Administrasi Bisnis dan D4 Administrasi Bisnis Terapan. Terdapat 4 kelas di Program Studi D3 Administrasi Bisnis dan 2 kelas di Program Studi D4 Administrasi Bisnis Terapan. Masingmasing terdapat 30 mahasiswa. Sampel dalam penelitian ini berjumlah 60 orang mahasiswa. Empat puluh sampel diambil dari Program Studi D3 Administrasi Bisnis dan 20 orang diambil dari Program Studi D4 Administrasi Bisnis Terapan. Sampel diambil secara acak.

Data dikumpulkan dengan menggunakan teknik kuesioner dan teknik dokumentasi. Teknik kuesioner digunakan untuk menjaring informasi tentang penyebab kesalahan bahasa Inggris dan faktor-faktor yang mempengaruhi timbulnya kesalahan. Teknik dokumentasi, yaitu berupa lembar hasil Ujian Akhir Mahasiswa Semester 1 pada Mata Kuliah English 1, digunakan untuk menemukan dan menetapkan jenis-jenis kesalahan bahasa Inggris pada tingkat kesalahan linguistik dan kesalahan bentuk.

Penelitian ini menggunakan metode kualitatif sesuai jenis data yang dihinpun. Data selanjutnya dihimpun dan digolongkan menurut teknik klasifikasi dan teknik penggolongan atas jenis-jenis kesalahan yang ditemukan. Dalam melakukan analisis data penelitian, langkah-langkah yang ditempuh peneliti adalah:
1. Menghitung jumlah kalimat yang dibuat dalam ujian akhir semester.

2. Mengidentifikasi kesalahan tiap kalimat

3. Mengidentifikasi kesalahan tiap teks

4. Menghitung jumlah kesalahan pada tiap teks

5. Mengklasifikasi kesalahan pada tiap teks

6. Menganalisis kesalahan

7. Menghitung rata-rata tiap jenis kesalahan

8. Mendeskripsi kesalahan

Data yang telah terkumpul diukur kebenarannya dengan menggunakan standar baku yang berlaku. Standar yang berlaku dan masih digunakan adalah kaidah yang tersebut dalam Harbrace College Handbook (1977), Common Mistakes in English (1982), dan A Practical English Grammar (1982).

\section{HASIL DAN PEMBAHASAN Jenis Kesalahan Yang Dibuat Oleh Mahasiswa}

Ditemukan 38 jenis kesalahan yang dibuat oleh mahasiswa dalam membuat teks ekspositori dalam mengerjakan Ujian Akhir Semester English 1 yang terdiri dari kesalahan berkaitan dengan pembentukan kalimat, (seperti tenses, subjek, predikat, verb agreement, dan keterangan), bentuk kata (article, preposition, noun phrases) dan jenis kata, kosakata dan ejaan, dan tanda baca (mechanics of writing). Di samping itu, ditemukan kesalahan akibat pengaruh Bahasa Indonesia. Terdapat masing-masing 9 orang mahasiswa (15\%) yang membuat kesalahan antara 4-7 jenis kesalahan. Delapan orang mahasiswa $(13,3 \%)$ membuat 9 jenis kesalahan, 6 orang mahasiswa (10\%) membuat 8 jenis kesalahan, 5 orang mahasiswa $(8,3 \%)$ membuat 3 jenis kesalahan, 3 orang mahasiswa (5\%) membuat 11 jenis kesalahan, dan hanya seorang mahasiswa $(1,7 \%)$ masing-masing membuat 2 jenis kesalahan dan 13 jenis kesalahan (lihat Tabel 3). Jika dirata-ratakan, maka setiap 
mahasiswa telah membuat 6 jenis kesalahan.

Tabel 1. Jumlah Jenis Kesalahan Yang Dibuat Mahasiswa

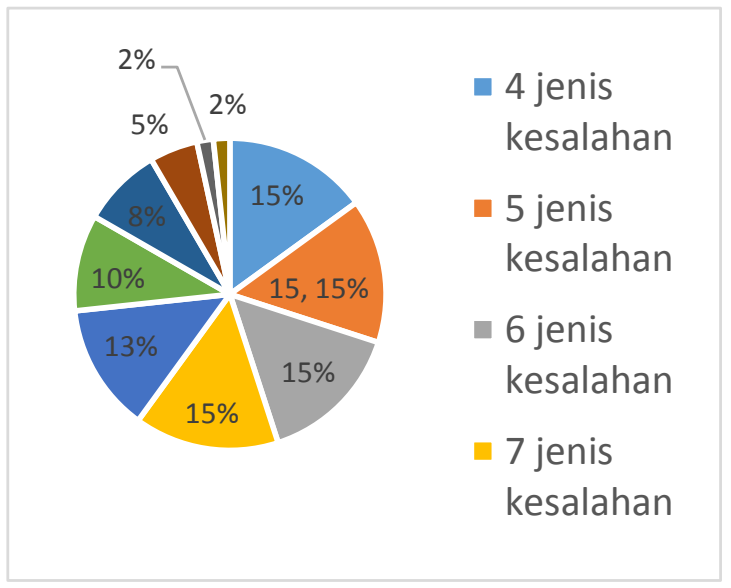

Enam kesalahan yang paling banyak dibuat oleh mahasiswa secara berurut adalah (1) 46 orang mahasiswa atau $76,7 \%$ sampel lupa tidak memberi tanda “titik" di akhir kalimat, (2) 35 orang mahasiswa atau 58\% sampel menulis koma padahal seharusnya titik atau titik koma, (3) 26 orang mahasiswa atau 43,3\% sampel membuat kekeliruan dalam penggunaan kosakata yang salah satunya adalah mereka tidak tahu perbedaan city dan big city, (4) 25 orang mahasiswa atau $41,7 \%$ sampel mengabaikan bentuk plural untuk kata benda jamak, (5) 22 orang mahasiswa atau $36,7 \%$ sampel masih gagal membuat kalimat karena tidak ada predikat, dan (6) 18 orang mahasiswa $30 \%$ sampel membuat kesalahan tentang kesesuaian subjek dan predikat (Verb Agreement). Sepuluh kesalahan terbanyak yang dibuat oleh mahasiswa secara berurut dapat dilihat di tabel di bawah ini.
Tabel 2. Jumlah Mahasiswa dan Jenis Kesalahan Yang Dibuatnya

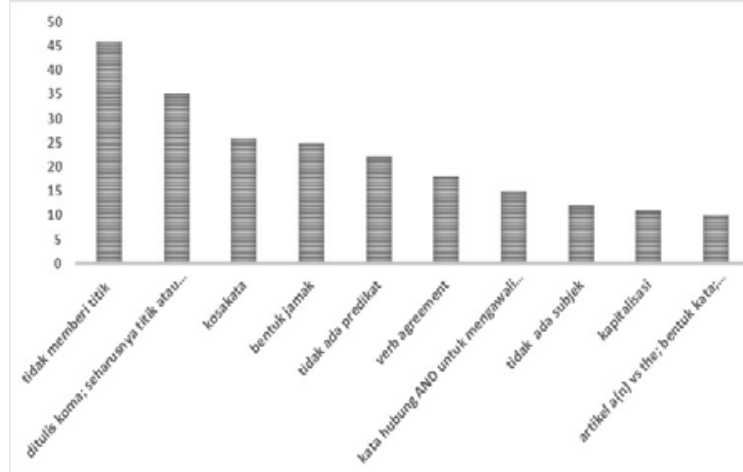

Pada umumnya mahasiswa Administrasi Niaga membuat kesalahan yang berkaitan dengan tanda baca terutama fungsi "titik", "titik koma”, dan "koma”. Mahasiswa seringkali memberi tanda koma (35 orang mahasiswa atau 58\% sampel) bukannya "titik" atau "titik koma” ketika kalimat yang sempurna telah dibuat (contohnya: Jakarta is good for study. There are more than more 100 schools and universities, (koma) 3 of them are State University of Jakarta. Seharusnya: Jakarta is good for study. There are more than more 100 schools and universities; 3 of them are State University of Jakarta). Bahkan hampir semua mahasiwa (46 orang mahasiswa atau $76,7 \%$ sampel) lupa tidak memberi tanda "titik" ketika sebuah kalimat yang sempurna telah dibuat. Hal ini berarti mahasiswa perlu dipahamkan lagi tentang penggunaan ketiga tanda baca tersebut agar mahasiswa tidak lagi membuat kesalahan.

Hampir separuh mahasiswa yang dijadikan sampel (26 orang mahasiswa atau 43,3\%) membuat kesalahan berkaitan dengan kosakata seperti "University of Brawijaya is a leading university in Indonesia with over 30,000 students in range in 16 faculties”. Kata yang bergaris bawah merupakan kosakata yang tidak tepat yang seharusnya adalah cukup in saja. Ada juga mahasiswa yang menuliskan "Kristen" yang berarti "agama” yang seharusnya ditulis Protestant. Contoh lainnya adalah "Jakarta is the capital city of Indonesia, so the 
economic turn round is very fast” yang seharusnya adalah "economic turn over" dan "very fast" yang mestinya "very high".

Selanjutnya ada 5 jenis kesalahan yang dibuat oleh mahasiswa berkaitan dengan pembentukan kalimat dalam bahasa Inggris ketika membuat teks atau cerita eksposisi pada saat Ujian Akhir Semester English 1: kalimat tidak berpredikat atau predikatnya kurang (36,7\% sampel) seperti, "Luar Batang mosque beside bank museum" (seharusnya ada predikat is) dan "TMII located to the south east of Jakarta city center" (kurang kata kerja is sebagai predikat setelah “Jakarta”); Subjek dan predikat yang tidak setara (agreement) (30\% sampel) seperti dalam kalimat berikut "Monas have a garden which is ..." (seharusnya Monas is); Kata hubung “AND” yang dipakai untuk mengawali kalimat (25\% sampel), kalimat yang tidak bersubjek (20\% sampel), seperti Green Business Center is to the southwest of city center. $10 \mathrm{~km}$ away (kurang IT IS); dan mahasiswa tidak dapat membuat kalimat pasif (15\% sampel) seperti Indonesia location between the Indian and Pacific oceans yang seharusnya is located atau "Indonesia is officially recognized 6 religions” yang seharusnya cukup recognizes.

Mahasiswa juga ternyata masih membuat kesalahan dalam menggunakan jenis kata yang tepat seperti, National Gallery, popularity known as Galnas is an art, ... yang seharusnya popularly atau important celebrate yang seharusnya important celebration; Mahasiswa juga tidak dapat membedakan antara its dan it's seperti dalam "Its about $7.5 \mathrm{~km}$ away" yang seharusnya "It is" atau Other religion in Indonesia include Hindu, Buddhism, and Kristen (yang seharusnya adalah Protestant). Detail kesalahan tersebut dapat dilihat di Lampiran 1.

Di samping kesalahan tersebut di atas, mahasiswa juga masih membuat kesalahan dalam pembentukan kalimat dengan menjadikan 2 kata kerja sebagai predikat seperti dalam "It is open from 8 to 16 " yang seharusnya "It opens from 8 to 16 ". Mahasiswa juga terkadang masih bingung dengan there are atau it is seperti dalam "There are about 6 minutes away by car" seharusnya "it is about 6 minutes away by car”, there atau they seperti dalam "Indonesia recognizes 6 religions. There are Islam, Protestant,...." yang seharusnya they. Mahasiswa juga masih tidak dapat membedakan antara city vs big city. Menurutnya, Jakarta, Bandung, Denpasar adalah big city sedangkan Bogor, Sukabumi, Depok adalah city bukannya town juga.

Mahasiswa juga seringkali masih terpengaruh oleh Bahasa Indonesia seperti dalam "Hospital in Jakarta there are Abdi Waluyo hospital, Jakarta hospital,...." yang seharusnya tidak perlu kata hospital di awal kalimat atau "Bahasa Indonesia is popular in Australia and become college in Australia" terjemahan langsung dari "menjadi mata kuliah". Mahasiswa juga belum menguasai pembentuk frasa benda (noun phrase/kata majemuk?) yang berfungsi sebagai subjek seperti "Indonsia is the fourth most populous in the world" yang seharusnya populous country atau "political of Indonesia is a republic" yang seharusnya Indonesia political system is ..." atau "Indonesia is located between continent Australia and Asia" yang seharusnya Australian continent.

Pemahaman mahasiswa terhadap kapitalisasi dan ejaan kata juga masih lemah. Awal kalimat seringkali tidak dimulai dengan huruf kapital. Di samping AND, mahasiswa juga masih mengawali kalimat dengan angka dan dengan kata hubung ALSO dan BECAUSE. Begitu pula huruf kapital untuk nama benda. Mahasiswa juga sering mengabaikan ejaan, bentuk jamak kata benda, dan kata depan (preposition) yang tepat dalam Bahasa Inggris seperti on east Java yang seharusnya in atau "Located of the northwest coast world most populous island of Java, ...” yang seharusnya in. 


\section{Signifikansi Kesalahan}

Berdasarkan 10 kesalahan terbanyak yang dibuat oleh mahasiswa, mahasiswa masih dominan membuat kesalahan pada pembuatan kalimat (sentence construction) yang benar. Beberapa hal yang perlu diperhatikan di antaranya mahasiswa masih sering kelupaan kata kerja yang berfungsi sebagai predikat, kesesuaian subjek dan predikat, dan menggunakan kata hubung dan angka untuk mengawali sebuah kalimat. Di samping itu, mahasiswa juga lupa mengunakan huruf kapital untuk mengawali kalimat atau untuk nama sebuah objek dan lupa bentuk jamak sebuah kata benda (pluralization). Beberapa mahasiswa juga lemah tentang bentuk kata (derivation) dan pembentukan kata majemuk (noun phrase). Meskipun sebagian besar mahasiswa tidak memperhatikan fungsi tanda baca khususnya "titik", "koma”, dan "titik koma”, tetapi hal ini juga merupakan kesalahan yang signifikan yang perlu diperbaiki..

\section{Perbandingan Kemampuan Peserta Didik Pria dan Peserta Didik Wanita Dalam Membuat Teks Eksposisi}

Dalam penelitian ini, perbandingan peserta didik pria dan peserta didik wanita adalah 11 orang berbanding 49 orang atau 18,3 persen berbanding 81,7 persen. Jumlah peserta didik pria yang mendapatkan nilai A sebanyak 1 orang sedangkan peserta didik wanita adalah sebanyak 39 orang. Peserta didik pria yang mendapatkan nilai B sebanyak 8 orang dan peserta didik wanita juga sebanyak 8 orang, sedangkan peserta didik pria yang mendapat nilai $\mathrm{C}$ sebanyak 2 orang dan peserta didik wanita juga 2 orang. Lihat tabel di bawah ini.
Tabel 3. Responden Berdasarkan Jenis Kelamin

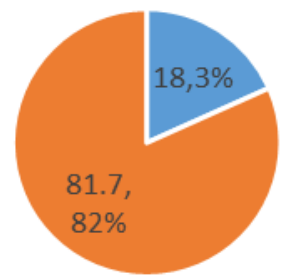

- Mahasiswa

- Mahasiswi

Tabel 4. Perbandingan Mahasiswa Dan Mahasiswi Per Nilai

\begin{tabular}{llrl}
\hline NO & NILAI & MAHASISWA & \multicolumn{1}{c}{ MAHASISWI } \\
\hline 1 & A & 1 orang (9,09\%) & 39 orang (79,6\%) \\
2 & B & 8 orang (72,7\%) & 8 orang (16,3\%) \\
3 & C & 2 orang (18,2\%) & 2 orang (4,09\%)
\end{tabular}

Berasarkan tabel tersebut di atas dapat ditafsirkan bahwa peserta didik pria pada umumnya hanya mendapatkan nilai "B" sedangkan peserta didik wanita mendapatkan nilai "A" $\quad(79,6 \%$ berbanding 9,09\%). Peserta didik pria yang memperoleh nilai "C" sebanyak $18,2 \%$ berbanding peserta didik wanita sebanyak 4,09\%. Dengan kata lain, peserta didik pria dapat diduga untuk membuat kesalahan lebih banyak dari pada peserta didik wanita.

Kisaran (range) jenis kesalahan yang dibuat peserta didik pria adalah 5. Peserta didik pria membuat antara 4--9 jenis kesalahan; Sementara itu, kisaran jenis kesalahan yang dibuat peserta didik wanita adalah 11. Artinya ditemukan peserta didik wanita yang hanya membuat 2 jenis kesalahan meskipun juga terdapat peserta didik wanita yang membuat 13 jenis kesalahan. Hasil penelitian ini pun menemukan bahwa peserta didik pria hanya mampu membuat teks ekspositori rata-rata sebanyak 49 kalimat. Sebaliknya peserta didik wanita mampu membuat teks ekspositori rata-rata sebanyak 61 kalimat.

Tabel 5. Perbandingan Kemampuan Peserta Didik Pria dan Peserta Didik Wanita

\begin{tabular}{llll}
\hline NO & & MAHASISWA & MAHASISWI \\
\hline 1 & $\begin{array}{l}\text { Jenis } \\
\text { Kesalahan }\end{array}$ & $4-9$ & $2-13$ \\
2 & Kalimat & 49 & 61 \\
\hline
\end{tabular}




\section{Perbandingan Kemampuan Mahasiswa Yang Berasal Dari SMU dan Yang Berasal Dari SMK}

Dalam penelitian ini, responden yang berasal dari SMU sebanyak 46 orang atau 76,7 persen dan responden yang berasal dari SMK sebanyak 14 orang atau 23,3 persen. Responden yang berasal dari SMU Negeri di Jakarta sebanyak 21 orang atau 45,7 persen, SMU Negeri di Bogor, Depok, Tangerang, dan Bekasi (Bodetabek) sebanyak 17 orang atau 36,9 persen, dan SMU Negeri di luar Jabodetabek sebanyak 7 orang atau 15,2 persen dan 1 orang atau sebanyak 2,17 persen berasal dari SMU Swasta di Jabodetabek. Dari responden yang berasal dari SMK sebanyak 14 orang atau 23,3 persen, 5 orang atau 35,7 persen berasal dari SMK Negeri di Jakarta, 6 orang atau 42,9 persen berasal dari SMK Negeri di Bodetabek, dan 3 orang atau 21,4 persen berasal dari SMK Swasta di Jabodetabek. Sementara itu, mahasiswa yang berasal dari SMU Swasta 1 Jabodetabek orang dan SMK Swasta yang berasal dari luar Jabodetabek tidak ada.

Dari hasil penelitian, hasil UAS mahasiswa yang berasal dari SMK, 10 orang atau 71,4 persen mendapatkan nilai A, 3 orang atau 21,4 persen mendapatkan nilai B, dan hanya seorang atau 7,2 persen yang mendapatkan nilai C. Sementara itu, hasil UAS mahasiswa yang berasal dari SMU yang mendatkan nilai A adalah 30 orang atau 65,2 persen, nilai B 14 orang atau 30,4 persen, nilai $C$ sebanyak 2 orang atau 4,4 persen. Hal ini berarti mahasiswa yang berasal dari SMK lebih baik dalam dalam menguasai bahasa Inggris English 1 dibanding mahasiswa yang berasal dari SMU. Lihat tabel di bawah ini.
Tabel 6. Perbandingan Nilai Berdasarkan Asal Sekolah: SMU vs SMK

\begin{tabular}{|c|c|c|c|}
\hline $\mathrm{NO}$ & NILAI & SMU & SMK \\
\hline 1 & $\mathrm{~A}$ & $\begin{array}{ll}30 & \text { orang } \\
(65,2 \%) & \end{array}$ & $\begin{array}{ll}10 & \text { orang } \\
(71,4 \%) & \end{array}$ \\
\hline 2 & B & $\begin{array}{l}14 \text { orang } \\
(30,4 \%)\end{array}$ & 3 orang $(21,4 \%$ \\
\hline 3 & $\mathrm{C}$ & 2 orang $(4,4 \%)$ & 1 orang $(7,2 \%)$ \\
\hline
\end{tabular}

Berdasarkan tabel tersebut di atas, mahasiswa yang mendapatkan nilai " $\mathrm{C}$ " yang berasal dari SMK lebih banyak dibanding mahasiswa yang berasal dari SMU (7,2\% berbanding 4,4\%). Akan tetapi, mahasiswa yang berasal dari SMU tidak lebih baik dibanding mahasiswa yang berasal dari SMK karena mahasiswa yang berasal dari SMK yang mendapatkan nilai "A" lebih banyak dibanding mahasiswa yang berasal dari SMU.

\section{KESIMPULAN DAN SARAN Kesimpulan}

Berdasarkan 10 kesalahan terbanyak yang dibuat oleh mahasiswa, pada dasarnya mahasiswa mampu mengingat dan menulis ulang kalimat dengan benar. Namun, ada beberapa temuan yang perlu diperhatikan ketika mahasiswa menulis dalam Bahasa Inggris, di antaranya yaitu (1) mahasiswa masih sering kelupaan kata kerja atau to be yang berfungsi sebagai predikat, kesesuaian subjek dan predikat, (2) mahasiswa menggunakan kata hubung dan angka untuk mengawali sebuah kalimat. (3) mahasiswa lupa menggunakan huruf kapital untuk mengawali kalimat atau untuk nama sebuah objek dan bentuk jamak sebuah kata benda (pluralization), (4) mahasiswa belum memahami tentang bentuk kata (derivation) dan kata majemuk (noun phrase), dan (5) mahasiswa belum memahami fungsi tanda baca khususnya "titik", "koma”, dan "titik koma" pada kalimat.

Mahasiswa yang berasal dari SMK ternyata juga memiliki kemampuan yang lebih baik dibanding mahasiswa yang berasal dari SMU untuk membuat teks 
ekspositori. Namun, jumlah mereka memang ternyata lebih sedikit dibanding mahasiswa yang berasal dari SMU. Peserta didik wanita mendapatkan hasil yang lebih baik dibanding peserta didik pria dalam membuat teks ekspositori.

\section{Saran}

Untuk mengatasi kekurangan tersebut, pengajar sebaiknya mereview pembuatan kalimat Bahasa Inggris secara benar, mengingatkan tanda baca, kapitalisasi, pinjamakan kata benda (pluralization) dan rambu-rambu lainnya, seperti penggunaan kata hubung di awal kalimat dan penulisan angka di awal kalimat

\section{DAFTAR PUSTAKA}

Abbas, Saleh. (2006). Pembelajaran Bahasa Indonesia yang Efektif di Sekolah Dasar. Jakarta: Departemen Pedidikan Nasional.

Corder, S. Pit. 1981. Error Analysis and Interlanguage. Oxford: Oxford University Press

https://academicguides.waldenu.edu/writi ngcenter/grammar/sentencestructure

https://www.learnamericanenglishonline.c om/Orange\%20Level/O5\%20Comp ound-Complex\%20Sentences.html.

Fitikides. T.J. 1982. Common Mistakes in English. Essex England: Longman.

Hodges, John C dan Mary E, Whitten. 1977. Harbrace College Handbook. New York: Harcourt BraceJovanovich. Inc.

Muhsin, Muh. Arief. 2016. Analysing the Students Errors in Using Simple Present (A Case Study at Junior High School in Makassar). Pacific Science Review B: Humanities and Social Sciences. Volume 2, Issue 3, Pages 81-87.

Saville-Troike, M. (2006). Introducing Second Language Acquisition. (pp. 39-40). New York: Cambridge University Press.
Sejnost, R.L. \& Thiese, S.M. (2010). Building Content Literacy. Thousand Oaks, CA: Corwin Press. http://www.readingrockets.org/articl e/reading-and-scaffoldingekspositori-texts.

Supritnoko dan Nurhasyim (1993).

Analisis Kesalahan Penggunaan

Bahasa Idonesia dalam Laporan

Tugas Akhir Mahasiswa Politeknik Universitas Indonesia: Universitas Indonesia: Laporan Penelitian.

Supriatnoko dan Ade Sukma Mulya (2005). Analisis Kesalahan Bahasa Inggris dalam Artikel Jurnal Ilmiah. Jurnal Bahasa \& Sastra. Vol. 6 No. 1 April 2006. FPBS UPI Bandung.

Thomson, A.J dan A.V. Martinet. 1982.

A Practical English Grammar. Oxford: OUP.

Tizazu, Yoseph. 2014. A Linguistic Analysis of Errors In Learners' Compositions: The Case Of Arba Minch University Students: International Journal of English Language and Linguistics Research Vol. 2, No. 2, pp. 69-101, June 2014. 